\title{
THE EFFECTS OF IMPLEMENTING THE SYDNEY SCHOOL GENRE-BASED APPROACH IN A THAI EFL WRITING CLASSROOM
}

\author{
Napak-On Sritrakarn \\ English for International Communication Program, Faculty of Technical Education, \\ Rajamangala University of Technology Isan, Khon Kaen Campus (Thailand)
}

\begin{abstract}
This paper reports on students' writing improvements after the application of the Systemic Functional Linguistic (SFL) genre-based approach. The research participants were 37 students who enrolled in the English Report Writing Course. In this study, the approach was employed in the teaching of three genres (description, report, explanation). Similar findings were shown after analysing students' writing drafts of the three genres in that students gained control over the key features of the required genres, however, grammatical mistakes at clause level still existed. This paper discusses how the approach helps students improve their writing. Due to the limitation of space, students' writing on one genre (description) will be illustrated and discussed. This paper will also discuss some implications in terms of language learning and teaching.
\end{abstract}

Keywords: Writing skills, SFL genre-based approach, description.

\section{Introduction}

Writing is often a difficult skill for students regardless of any learning contexts in which they are located. It is not a technology, but involves a set of skills which must be practiced and learned through experiences (Pribady, 2012). For this reason, the writing process requires guidelines, training, practices and comments for improvements. Given that writing for different purposes deploys the resources for meaning-making through the grammar in different ways (Gerot \& Wignell, 1994), this makes the writing process even harder for language learners. Especially for non-native speaking learners, the writing goals and explicit guidelines of how to compose different texts are considered as necessary. It is therefore important that EFL teachers find the best ways to support their students to construct the texts which successfully achieve different purposes. The present study employed the Systemic Functional Linguistic (SFL) or Sydney school genre-based approach (an approach to writing which focuses on the relationship between written texts and the contexts in which written texts are produced- Hammond, 1987) in a writing classroom of a university in Thailand to teach three different kinds of texts: description, report and explanation. This paper demonstrates students' writing on one text type: a description. The study aimed to answer the research question below.

1. Can the SFL genre-based approach help students improve their writing of a description? And in which way?

\section{Literature review}

\subsection{The concept of genre-based approach}

Genre in SFL's perspective is defined as a staged, goal-oriented, purposeful activity in which speakers engage as members of our culture (Martin, 1984: 25). It is "social because we participate in genres with other people; goal oriented because we use genres to get things done; staged because it usually takes us a few steps to reach our goals" (Martin \& Rose, 2007: 8). Moreover, texts are classified based on the variations of: field (the social activities and topics that relate to the chosen situation), tenor (the relationships of those involved in the situation), and mode (whether they are spoken or written- Feez, 2002: 62). Field, tenor, and mode are register variables which have the role to predict particular patterns of language that will be used in different situated texts. In this way, the language used in an explanation of how waste water is recycled (field) written in a textbook (mode) for engineering students (tenor) would 
be different to that used in a recipe of how to cook a beef pie (field) published in a cookbook (mode) for any interested readers (tenor). Based on these certain forms of language required for the communication of different social goals, scholars claim that the SFL genre-based approach has the potential to provide model, guidelines and help students improve their writing of different text types (e.g. Chaisiri, 2010; Kongpetch, 2006; Payaprom, Srinon, 2010).

\subsection{The teaching and learning cycle}

The instructional process of the Sydney school genre-based approach follows a wheel model of a teaching and learning cycle consisting of three stages: deconstruction (the target genre is introduced to students); joint construction (students carry out exercises, reading, researching, disseminating information, and compositing a text of the required genre in groups); and independent construction of texts (students produce actual texts independently- Hammond, et al, 1992).

\subsection{The focused genre}

The focused genre in this study was a description. A description aims to describe a particular person, place or thing (Hammond et al, 1992). Table 1 below demonstrates a model text of a description. The situated text is constructed as a description of an animal (field) shared by a knower for passengers (tenor) published in a column of the airline magazine (mode). Table 1 below presents the schematic structure and significant linguistic features of a description.

Table 1. Sample text of a description (taken from: AirAsia Inflight Magazine, 2017:50).

\begin{tabular}{|c|c|c|}
\hline $\begin{array}{l}\text { Schematic } \\
\text { structure }\end{array}$ & Text & Significant grammatical patterns \\
\hline Identification & $\begin{array}{l}\text { The Lionhead rabbit is another easily- } \\
\text { [recognizable] creature, simply because it has } \\
\text { fur like a lion' mane! }\end{array}$ & \multirow[b]{2}{*}{$\begin{array}{l}\text {--Focus on specific rather than generic } \\
\text { participants (Bold) } \\
\text {--Simple present tense } \\
\text {--Verbs of being and having (Underlined) } \\
\text {--Use of descriptive adjectives to build up long } \\
\text { nominal groups [Brackets] }\end{array}$} \\
\hline Description & $\begin{array}{l}\text { These cute bunnies come from Belgium, and } \\
\text { are mostly [brown], [black] or [white] in } \\
\text { colour. They are an [intelligent] species and } \\
\text { can be trained to do a [wide] variety of tricks- } \\
\text { they can even be potty trained! The } \\
\text { Lionhead rabbit is the [perfect] first pet to } \\
\text { initiate children into the world of pet } \\
\text { ownership. }\end{array}$ & \\
\hline
\end{tabular}

\section{Methodology}

The students who participated in this study were 37 (5 males and 32 females) English majored- sophomores who were undertaking the English Report Writing Course in the second semester of academic year 2018. Their level of English proficiency was intermediate. This group of students enrolled in the Essay Writing Course prior to undertaking the investigated course.

English Report Writing was a compulsory course for English majored students in the context of study. The course aims to enhance students' knowledge of writing principles and necessary language for report compositions, develop students' research skills from different sources, practice writing different kinds of report, proposals, and referencing. In this study, students were practicing how to write three different kinds of genres, namely: description, report and explanation, through the Sydney school genre-based approach.

In the first week of the semester, the teacher made a brief overview of the course and introduced the SFL genre-based approach. The stages of the teaching and learning cycle were also introduced and explained to the class as the learning process to be organised in the classroom. To begin the lesson of a description, students were asked to write their first drafts on the topic assigned. Then, the instruction was conducted through the SFL genre- based approach, following the stages of the teaching and learning cycle. After that, students were told to revise the first drafts and make changes, based on the learnt knowledge. Students then submitted their second drafts to receive feedback from the teacher. After students edited their second drafts, they submitted the final drafts.

After students got familiar with the SFL genre-based approach, the instructions of the next lessons (report and explanation) were conducted through the teaching and learning cycle. Students composed their first drafts after the instruction and submitted their final drafts after receiving the teacher feedback. Altogether, students composed two drafts in these two lessons. 
To analyse the data, students' writing (first and final drafts) were examined and compared in terms of writing goals, generic stages, and significant language features.

\section{Findings}

Prior to the intervention, students were assigned to write draft 1 . The task was for them to describe about the place they had just visited in the previous week (Koh Change Island, Trat) as part of the English for Tourism Course. Students were told to imagine that they were working as a tourist guide and had to write a report about the facts of the city to provide information to tourists.

The analysis of students' first drafts showed that most students composed their drafts which have got the language features of a recount (a text which retells event for the purpose of informing or entertaining- Gerot \& Wignell, 1994). According to Gerot \& Wignell (1994), a recount is composed of three main stages: Orientation (provides the setting and introduces participants) $\wedge$ Events (tell what happened in what sequence) $\wedge$ [Re-orientation] (closure of events). The symbol ^ denotes "followed by" and [ ] denotes an optional stage. Table 2 below demonstrates the writing draft of Yindee, an advance learner, composed in the structure of a recount.

Table 2. Sample of students' first draft.

\begin{tabular}{|c|c|c|}
\hline \multirow{2}{*}{$\begin{array}{l}\text { Schematic } \\
\text { structure }\end{array}$} & Text & \multirow{2}{*}{$\begin{array}{c}\text { Significant } \\
\text { grammatical } \\
\text { patterns }\end{array}$} \\
\hline & yindee (High achiever) & \\
\hline Orientation & $\begin{array}{l}\text { Last week } \mathbf{I} \text { had a nice trip in Trat province with } \mathbf{m y} \text { beloved teacher and } \\
\text { my lovely classmates. The trip was fabulous and } \mathbf{I} \text { had a really good time } \\
\text { with my favourite humans. }\end{array}$ & \multirow{3}{*}{$\begin{array}{l}\text {--introduce } \\
\text { personal } \\
\text { participants (Bold) } \\
\text {--use chronological } \\
\text { connection } \\
\text { (Underlined) } \\
\text {--use of linking } \\
\text { words (Italics) } \\
\text {--use of action verb } \\
\text { in simple past } \\
\text { tense [Brackets] }\end{array}$} \\
\hline Events & $\begin{array}{l}\text { The trip lasted three days and two nights. Begin with the day one, our } \\
\text { destination was Ban Taranae. The bus [left] at } 4.00 \text { a.m. from my university } \\
\text { toward to Chantaburi; the eastern province of Thailand. We [arrived] at } \\
\text { Krua Lung Cjaey; one of a famous local restaurant in Chantaburi province } \\
\text { about } 1.05 \text { p.m. We had a nice lunch there. My favourite food was Loan Pu. } \\
\text { It was very good taste and I loved it a lot. After lunch we [continued] our } \\
\text { journey to BanTaranae which is located in Trat province. After spending a } \\
\text { long time on the bus we finally arrived Ban Taranae about } 2.50 \text { p.m. The } \\
\text { hosts [gave] us a warm welcome and the whole villagers were friendly. I } \\
\text { had a great time there. I [did] many fun activities; tasting local cakes, } \\
\text { taking the boat to enjoy the view of mangrove forest; learning local life; } \\
\text { planting mangrove tree and having a wonderful dinner. } \\
\text { For the second day of the trip, we [continued] our trip to Koh Chang. We } \\
\text { [arrived] at Koh Chang Ferry Terminal about } 10.40 \text { a.m. Then, we [took] a } \\
\text { big ferry boat toward the Kh=oh Chang. We [arrived] at Magic Resort } \\
\text { about } 11.30 \text {. the resort was a kind of bungalows. The room was nice and } \\
\text { the services were good with interesting prices. I enjoyed my time a lot. I } \\
\text { [took] a lot of photos and [walked] along the beach. I also [went] to Koh } \\
\text { Yuak. It was a beautiful island. The sea was as clear as mirror and the sands } \\
\text { were so nice. It was my first time there to dive into the sea. I saw so many } \\
\text { kinds of fish and many wonderful kinds of corals. In the evening we had } \\
\text { dinner on the beach and sang Karaoke. My second day trip was so great. } \\
\text { For the last day, after having breakfast at the resort. We [took] a huge ferry } \\
\text { back to Koh Chang Ferry Terminal. It was time to back hoe. We [stopped] } \\
\text { at A-Ah gift shop it's a big souvenir shop in Chantaburi. There were a lot of } \\
\text { local foods, local snacks and fruits. I [bought] some snacks for my friends. } \\
\text { And they [gave] me a good feedback. }\end{array}$ & \\
\hline $\begin{array}{l}\text { Re- } \\
\text { orientation }\end{array}$ & $\begin{array}{l}\text { Although our trip was a long journey trip and we [spent] almost of our time } \\
\text { on the bus, it can't deny that it was a wonderful trip. }\end{array}$ & \\
\hline
\end{tabular}

Table 2 shows that Yindee was not aware of the writing goal assigned in the task. She composed her draft as a recount, re-telling the activities she had done with her classmates.

After receiving comments from the teacher, Yindee edited her work and submitted the final draft. Table 3 clearly shows her ability to take control of the text by organising the final draft which successfully achieves the writing goal of a description and the text is composed of the two required schematic stages: Identification $\wedge$ Description. 
Table 3. Sample of students' final draft.

\begin{tabular}{|c|c|c|}
\hline \multirow{2}{*}{$\begin{array}{l}\text { Schematic } \\
\text { structure }\end{array}$} & Text & \multirow{2}{*}{$\begin{array}{c}\text { Significant } \\
\text { grammatical } \\
\text { patterns }\end{array}$} \\
\hline & Final draft & \\
\hline Identification & Trat $\underline{i s}$ the easternmost province along the Thai coast. & \\
\hline Description & 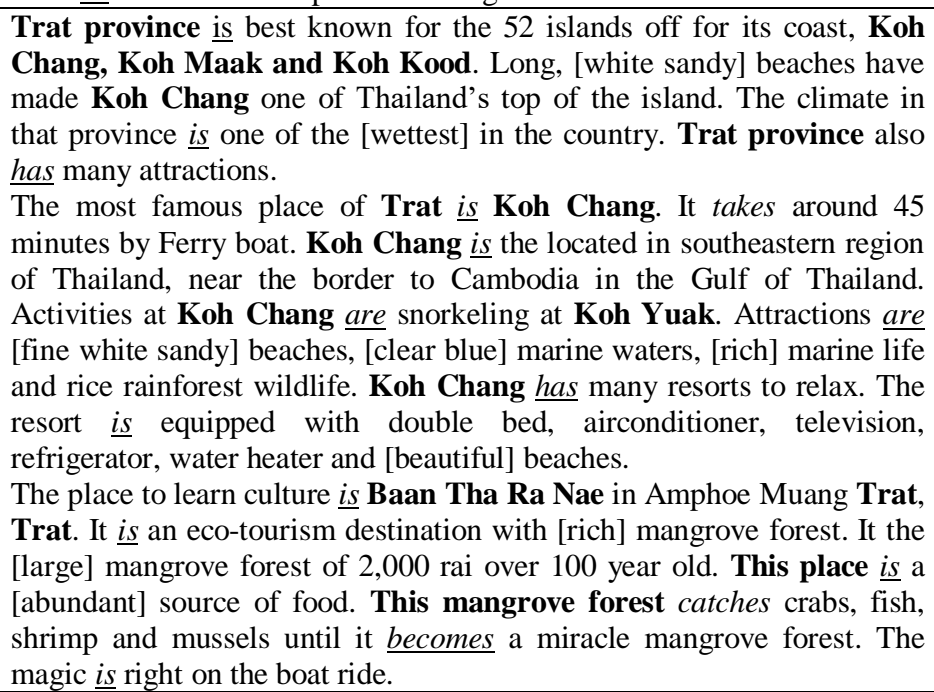 & $\begin{array}{l}\text {--Focus on specific } \\
\text { rather than generic } \\
\text { participants (Bold) } \\
\text {--Simple present } \\
\text { tense (Italics) } \\
\text {--Verbs of being and } \\
\text { having (Underlined) } \\
\text {-- Use of descriptive } \\
\text { adjectives to build up } \\
\text { long nominal groups } \\
\text { [Brackets] }\end{array}$ \\
\hline
\end{tabular}

The improvements in students' writing after learning through the Sydney school genre-based approach could also be found in other students' writing.

Despite these improvements at text level, students also demonstrated their better control of language at clause level, however; some problems in terms of grammar could still be found (for example "Trat province also has many attractions." "Koh Chang is the located in southeastern region of Thailand." "Koh Chang has many resorts to relax." "It the large mangrove forest."). This problem as well as other types of mistakes (including the use of word form and word structure) also existed in other students' writing, especially the poor learner group.

\section{Discussion}

The findings from this study have provided some implications for the teaching of writing and for future study.

First of all, the problems found in students' writing in terms of grammar and word form reflect the problems of students in the context of study. These findings are consistent with the claims from previous studies regarding the problems of Thai students in terms of grammar (e.g. Seetrakarn, 2017; Sukasame et al, 2013) and word structure (e.g. Rayupsri \& Kongpetch, 2014).

Moreover, the investigation of poor students' writing drafts showed that problems still existed after receiving feedback from the teacher. This implies the need of poor students for closer attention from the teacher and further feedback maybe provided to this group of learners, using the feedback types which are more explicit. Sritrakarn (2018) investigated the types of feedback which were most helpful for students' writing improvements and found that metalinguistic type (when the teacher provides some kind of metalinguistic clue as to the nature of the error- Ellis, 2009) was the most effective type. Further study may consider using this type of feedback when assessing their students' writing drafts.

The last implication is concerned with students' familiarity with the approach and theory. As SFL genre-based approach has not been widely employed in the Thai EFL learning context, some technical terms related to the tools of genre and register could be new and create challenges to students. SFL metalanguage should therefore be foregrounded at an early stage. Once students get familiar with the terms, the approach may be used more widely in other subjects for a variety of learning purposes, for example, in planning for, reflecting on, and assessing student literacy across the curriculum (Macken- Horarik, 2002: 18). 


\section{Conclusion}

This paper reports the results from the application of the SFL genre-based approach in a writing classroom. The findings showed that the approach could help students improve their writing drafts at a broad structure by constructing the texts which achieve the writing goal of the target genre. At discourse semantic level, students' texts were also organised successfully with the required schematic structure. The findings showed that students had shown the awareness of the required language features, however, problems in terms of grammar and word structures still existed. Based on the findings, the study proposes that further feedback maybe provided to students, in particular to the lower level learners, and that further study should focus on students' writing of other genres.

\section{References}

Air Asia. (2017). Furry companions. Travel 3sixty: AirAsia Inflight Magazine, 50.

Chaisiri, T. (2010). Implementing a genre pedagogy to the teaching of writing in a university context in Thailand. Language Education in Asia, 1, 181-199.

Ellis, R. (2009). A typology of written corrective feedback types. ELT Journal, 63(2), 93-107.

Feez, S. (2002). Heritage and innovation in second language education (pp. 43-70). In A. Johns (ed.). Genres in the classroom. Mahwah, NJ: Laurence Erlbaum.

Gerot, P. \& Wignell, L. (1994). Making sense of functional grammar: An introductory workbook.

Cammeray, N.S.W.: Antipodean Educational Enterprises.

Hammond, J. (1987). An overview of the genre-based approach to the teaching of writing in Australia. Australian Review of Applied Linguistics, 10(2), 163-181.

Hammond, J., Burns, A., Joyce, H., Brosnan, D. \& Gerot, L. (1992). English for social purposes: A handbook for teachers of adult literacy. Sydney: National Centre for English Language Teaching and Research.

Kongpetch, S. (2006). Using a genre-based approach to teach writing to Thai students: A case study. Prospect, 21(2), 3-33.

Macken-Horarik, M. (2002). 'Something to shoot for': A systemic functional approach to teaching genre in secondary school science (pp. 21-46). In A. M. Johns (Ed.), Genre in the classroom. Mahwah, NJ: Erlbaum.

Martin, J.R. (1984). Language, register and genre (pp. 21-29). In F. Christie (Ed.). Children writing: Reader. Geelong, Victoria, Australia: Deakin University Press.

Martin, J.R. \& Rose, D. (2007). Genre relations: Mapping culture. London: Equinox.

Payaprom, S. (2012). The impact of a genre-based approach on English language teaching in an EFL tertiary context in Thailand. Unpublished PhD Thesis. Faculty of Education, University of Wollongong.

Pribady, I. (2012). The Implementation of Genre Based Approach to Teaching Narrative Writing. Proceeding of the 39th International Systemic Functional Linguistics Congress, 57-62.

Rayupsri, K., \& Kongpetch, S. (2014). Implementation of the process-genre approach in an English as a foreign language classroom in Thailand: A case study. RJES, 1(2), 32-53

Seetrakarn, Y. (2017). Teacher perceptions and course development: A case study. Journal of Humanities and Social Sciences, Burapha University, 25(7), 243-265.

Srinon, U. (2010). An investigation of generic structure development on the introduction of a genre- based approach into a Thai university's academic writing context. Proceeding of the ASFLA Conference, Practicing Theory: Expanding Understanding of Language, Literature and Literacy, held at the Queensland University of Technology, Brisbane, 30 September - 2 October.

Sritrakarn, N. (2018). A comparison of teacher's and senior students' feedback: Student attitudes and their writing improvement. The Journal of Asia TEFL, 15(2), 329-348.

Sukasame, N. Kantho, S. \& Narrot, P. (2013). A study of errors in learning English grammatical structures on Tenses of Matthayomsuksa 4 students of the demonstration school, Khon Kaen

University. Procedia: Social and Behavioral Sciences. 116(2014), 1934-1939. 